\title{
Title:
}

\section{Lenvatinib in severe hypoglycemia associated with hepatocellular carcinoma}

\section{Authors:}

Katherine Milagros Gómez Torres, Carmen Molina Villalba, Matías Estévez Escobar

DOI: $10.17235 /$ reed.2021.8016/2021

Link: PubMed (Epub ahead of print)

Please cite this article as:

Gómez Torres Katherine Milagros, Molina Villalba Carmen, Estévez Escobar Matías. Lenvatinib in severe hypoglycemia associated with hepatocellular carcinoma. Rev Esp Enferm Dig 2021. doi:

10.17235/reed.2021.8016/2021.

This is a PDF file of an unedited manuscript that has been accepted for publication. As a service to our customers we are providing this early version of the manuscript. The manuscript will undergo copyediting, typesetting, and review of the resulting proof before it is published in its final form. Please note that during the production process errors may be discovered which could affect the content, and all legal disclaimers that apply to the journal pertain. 
CC 8016

\section{Lenvatinib in severe hypoglycemia associated with hepatocellular carcinoma}

Katherine Milagros Gómez Torres, Carmen Molina Villalba, and Matías Estévez Escobar Department of Gastroenterology. Hospital de Poniente. El Ejido, Almería. Spain

Correspondence: Katherine Milagros Gómez Torres

e-mail: katmigomez@gmail.com

Keywords: Hypoglycemia. Non-islet cell tumor. Hepatocellular carcinoma. IGF-2. Lenvatinib.

Conflicts of interest: the authors declare that they have no conflicts of interest.

Dear Editor,

We present the case of a 24 -year-old male with multicentric hepatocellular carcinoma (HCC) over HBV-related compensated liver cirrhosis, on treatment with sorafenib and tenofovir. He had multiple admissions in recent months for severe hypoglycemia episodes with neurological symptoms.

Serologic tests were requested given the suspicion of non-islet cell tumor hypoglycemia (NICTH), which revealed low insulin, proinsulin, C-peptide, and betahydroxybutyrate levels, the absence of anti-insulin antibodies, and an IGF-2/IGF-1 ratio of 20.4. He was not eligible for tumor debulking because of a low liver reserve. Sorafenib was changed to lenvatinib given the patient's difficult glycemic control with oral diet, oral glucose solutions, and corticosteroids. Glycemic control improved in a few days, glucose intravenous infusions were suspended, and the patient was discharged. He required a new admission 3 weeks later because of worsening and a torpid evolution of his HCC, with a fatal outcome. 


\section{DISCUSSION}

Hypoglycemia in HCC is usually multifactorial. NICTH is an infrequent paraneoplastic syndrome, probably underdiagnosed, severe, and difficult to manage, in the context of benign and malignant tumors, including HCC $(1,2)$.

NICTH usually presents mainly with neuroglycopenic manifestations, which may constitute the presentation of HCC (2). It is characterized by excessive production of prolGF-2 and IGF-2, as well as low levels of insulin, proinsulin, C-peptide, and betahydroxybutyrate. An IGF-2/IGF-1 ratio > 10 confirms the diagnosis (1-3).

Publications about NICTH management are scarce. Complete tumor resection is curative, but commonly contraindicated, therefore attempts are made to reduce tumor volume. If this is not possible, corticosteroid therapy may be effective (prednisone, 30-60 mg/day), with or without rhGH (3-12 mg/day). An alternative for short-term management is glucagon infusion $(1,3)$. Recent data suggest that lenvatinib, an oral receptor tyrosine kinase inhibitor with an antiangiogenic effect, may be a suitable alternative ( $8 \mathrm{mg} /$ day) (4).

NICTH should be suspected in the presence of refractory hypoinsulinic hypoglycemia in patients with HCC, mainly with neurological symptoms without a clear etiology. Its recognition will improve the quality of life of these patients, and lenvatinib could be a novel option in refractory cases with reduced functional reserve.

\section{REFERENCES}

1. Bodnar TW, Acevedo MJ, Pietropaolo M. Management of non-islet-cell tumor hypoglycemia: a clinical review. J Clin Endocrinol Metab 2014;99(3):713-22. DOI: 10.1210/jc.2013-3382

2. Yu B, Douli R, Suarez JA, et al. Non-islet cell tumor hypoglycemia as an initial presentation of hepatocellular carcinoma coupled with end-stage liver cirrhosis: A case report and review of literature. World J Hepatol 2020;12(8):519-24. DOI: 10.4254/wjh.v12.i8.519

3. Garla V, Sonani H, Palabindala V, et al. Non-islet Cell Hypoglycemia: Case Series and Review of the Literature. Front Endocrinol (Lausanne) 2019;10:316. DOI: 
10.3389/fendo.2019.00316

4. Izutsu T, Ito H, Fukuda I, et al. Early improvement of Non-islet Cell Tumor Hypoglycemia by chemotherapy using lenvatinib in a case with type 2 diabetes and hepatocellular carcinoma producing big IGF-II. Intern Med 60(9):1427-32. DOI: 10.2169/internalmedicine.5328-20 